Marina Vicelja Dino Milinović

\section{-Matijašić}

Odsjek za povijest umjetnosti

Filozofskog fakulteta

Sveučilišta u Rijeci

DOI:

10.17685/PERISTIL.60.14

\title{
Nova post vetera coepit Ikonografija prve kršćanske umjetnosti
}

Sveučilište u Zagrebu,

Filozofski fakultet,

FF press i Hrvatska sveučilišna naklada

Zagreb, 2016.

474 str.
Recenzenti:

Josip Belamarić, Igor Fisković i

Hrvoje Gračanin

ISBN 978-953-175-467-5 (FF), ISBN 978-953-169-364-6 (HSN)

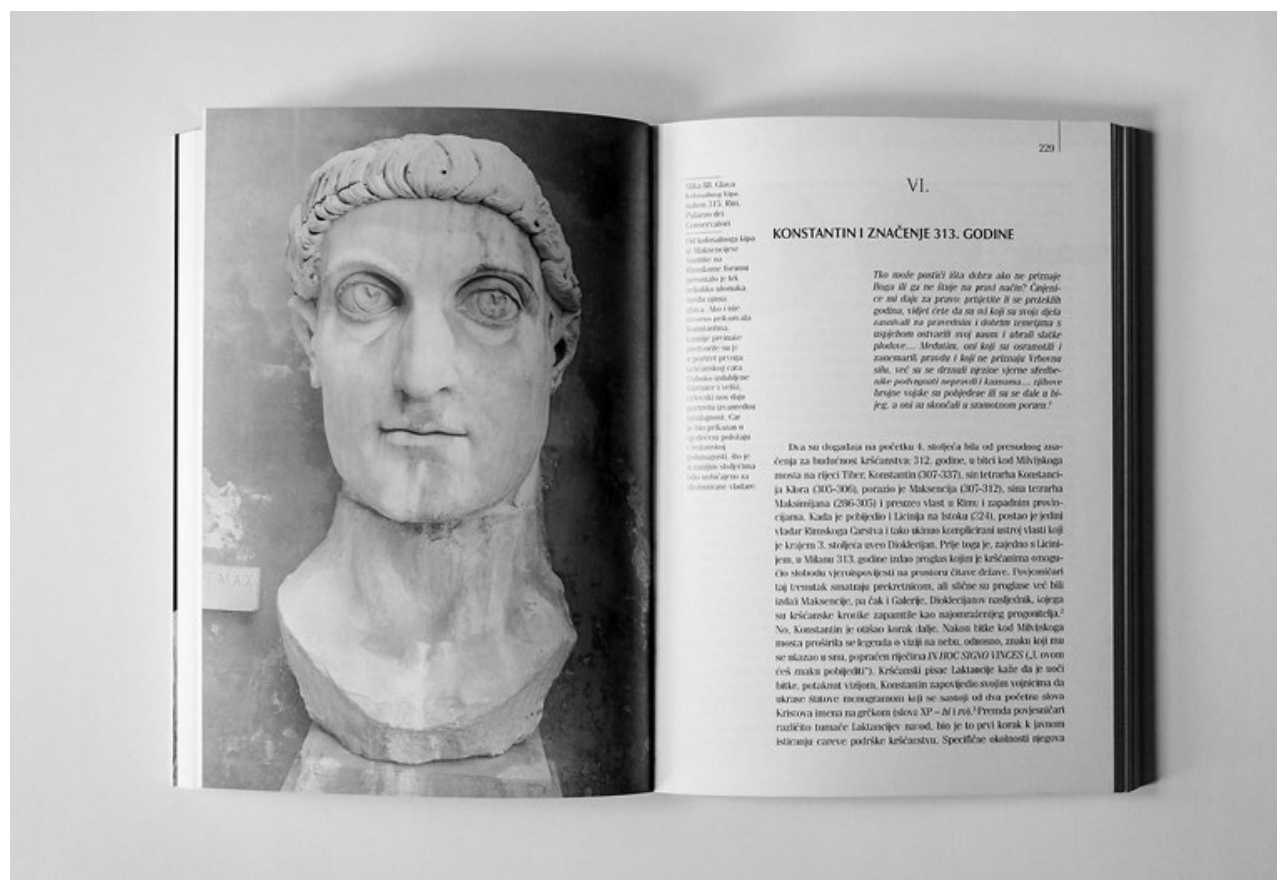

foto: Sanjin Kaštelan

\section{Povijest umjetnosti ranog kršćanstva: između dogme i discipline}

U izdanju Hrvatske sveučilišne naklade i Filozofskog fakulteta izašla je knjiga Dine Milinovića, profesora na Odsjeku za povijest umjetnosti Filozofskog fakulteta u Zagrebu, Nova post vetera coepit. Ikonografija prve kršćanske umjetnosti. Riječ je o iznimno vrijednom rukopisu koji nadilazi okvire sveučilišnog udžbenika, kako je kategoriziran, nego predstavlja temeljitu i metodološki suvremenu znanstvenu studiju o likovnim umjetnostima u razdoblju od 2. do 4. stoljeća. U analizi nastanka i razvoja rane kršćanske umjetnosti autor polazi od njezina povijesno-sociološkog i kulturološkog okvira - kasne antike - čija slojevitost i svestrano povijesno-istraživačko čitanje predstavljaju osnovu za razumijevanje smjernica toga razvoja, ponajprije prema ključnoj odrednici „kontinuitet ili prekid“. Milinović donosi sažet i dobro balansiran pregled različitih pristupa 
navedenoj problematici u 19. i 20. stoljeću te izdvaja nekoliko ključnih imena i djela, što je neophodan uvod za daljnje razmatranje.

Knjiga je podijeljena u tri dijela i osam poglavlja, u kojima autor interpretaciji i razumijevanju kršćanske umjetnosti prilazi ponajprije problemski, određujući kriterije, uzroke i posljedice o kojima raspravlja, zatim kronološki te na kraju i u raspravi o monumentalnoj naspram primijenjenoj umjetnosti, sa snažnom referencijom na Rieglove teze koje se često preskaču ili zaboravljaju u recentnoj literaturi. Tu promjenu ukusa od plastičnog prema plošnom, od naturalističkog prema apstraktnom, odnosno taktilnog prema optičnom, autor razmatra u posljednjem poglavlju u kojem na nizu primjera zaključuje svoju tezu o umjetnosti kasne antike kao produkciji obilježenoj suživotom, kontinuitetom i prilagodbama, a ne zabranama, rezovima i naglim promjenama $u$ formalnom i ikonografskom vokabularu. Prva kršćanska umjetnost, dakle, rađa se i razvija u okrilju snažne antičke tradicije koja će na nju neminovno utjecati, a o tim utjecajima i njihovim reperkusijama kroz nekoliko stoljeća raspravlja Milinović, dotičući se različitih problema kao što su ekonomska i politička kriza Carstva, smrt i sjećanje, nova religijska učenja i duhovni pravci, judaistički korijeni te pisana riječ i učenje kršćanskih otaca. U prvom poglavlju autor donosi prikaz društveno-političkih promjena i njihova dubokog i trajnog pečata na rimsko društvo, među kojima se ističu decentralizacija Carstva i izmjena uloge i percepcije carske ličnosti. Te će promjene, uz popratne nepovoljne ekonomske pokazatelje, obilježiti dokidanje jedinstvenosti Carstva na svim razinama, što će rezultirati jačanjem samostalnosti pojedinih provincija, budenjem autohtonih tradicija i novih duhovnih stremljenja pod utjecajem učenja s istoka. Time započinje nepovratno rastakanje helenističke tradicije, u dugom procesu preobrazbe klasične kulture. Najsnažniju je ulogu u tom procesu imao utjecaj misterijskih kultova, njihovih poruka, rituala i drugačijeg poimanja čovjekova postojanja i odnosa prema smrti, što će rasplamsati raspravu i potaknuti podijeljenost između pragmatične tradicionalne struje filozofa i zagovornika novog, idealističkog trenda na tragu Platonova učenja. U tom je intelektualnom ozračju koje zagovara postojanje vrhovnog uma kao vrhovnog dobra, položen temelj trijumfu kršćanstva koje brzo preuzima vodeću ulogu. Autor je najprije odredio obrise materijalne i duhovne bine na koju smješta likovnost i ulogu „slike“ u tom razdoblju. U likovnim umjetnostima Milinović na jasan i argumentiran način pokazuje zrcaljenje podijeljenosti, raznolikosti, suprotnosti i ponekad paradoksa kasnoantičkog društva. U istom vremenu njeguju se svijet spektakla, dekora, carskog portreta, monumentalne skulpture, raskošnih, teatralnih prikaza bitaka, lova, carskog ceremonijala i nove ikonografije slike pojednostavljenih, skromnih, snažno simboličnih ili ilustrativnih prikaza, mahom okrenutih religijskom/liturgijskom prostoru i upitnoga dekorativnog sadržaja. O tom novom izričaju autor raspravlja u drugom dijelu knjige posvećenom korijenima i nastanku kršćanske umjetnosti, koji započinje uvodom u judaistički likovni prostor, na koji će se kršćanstvo snažno osloniti. Peto je poglavlje posvećeno počecima kršćanske umjetnosti kao jedne od grana nove religioznosti i njezinoj evoluciji u prvim desetljećima razvoja. Autor ispravno navodi nemogućnost rekonstrukcije i točne datacije najranijih likovnih izričaja kršćanstva te naglašava činjenicu kako poticaj nastanku ove umjetnosti ne možemo tražiti u osmišljenom programu crkvenih vlasti nego u zagrobnim običajima i pučkoj pobožnosti, pa, slijedom toga, značajno poglavlje posvećuje likovnim ostacima u katakombama i drugim izričajima funeralnog karaktera. U ovom se odjeljku nadalje govori o radionicama, naručiteljima, prvoj crkvenoj (monumentalnoj) umjetnosti, tipološkim podjelama, motivici i ikonografskim programima te o značenju „slike“ u okviru novog, kršćanskog učenja i prostora. Na odabranim primjerima iz bogate riznice starozavjetnih i novozavjetnih tema te prvih dogmatskih sadržaja, autor objašnjava način pristupa, u kojem ne traži što slika prikazuje nego na koji način prenosi poruku.

U posljednjem, trećem dijelu Milinović se usredotočuje na 4. stoljeće, cara Konstantina te ključne događaje koji će promijeniti tijek povijesti kršćanstva i, posljedično, kršćanske umjetnosti. Poput svakoga dobrog udžbeničkog štiva na danu temu, i ovaj tekst velik prostor posvećuje Konstantinovu slavoluku, donoseći dijelom opće prihvaćene interpretativne elemente, a dijelom i autorove stavove u pitanjima njegova značenja, a poglavito recepcije spomenika s obzirom na neupitnu političku poruku (političke poruke), kojom je zračio u vrijeme nastanka, i koju je zadržao u stoljećima koja su uslijedila. Slavoluk u tekstu predstavlja i uvod u zahtjevniju raspravu o „konstantinskoj prekretnici“ i njezinim učincima na likovne 
umjetnosti, s referencijama na povijesne izvore i tekstualne predloške. U pretposljednjem odlomku dat je prikaz osnovnih smjernica u razvoju umjetnosti postkonstantinova razdoblja, u kojem se bilježi kvalitativni rast (i u izvedbi, i u ikonografski pročišćenim kompozicijama) što se prepoznaje, izmedu ostalog, u tzv. lijepom stilu - zasebnoj struji u izradi rimskih sarkofaga. Sarkofazima kao nositeljima specifičnog i prepoznatljivog sadržaja autor posvećuje posebno poglavlje, naglašavajući njihovu dominantnu ulogu u formiranju i promicanju sad već monumentalne kršćanske ikonografije. Pomnom studijom rimskih sarkofaga Milinović ujedno potvrđuje Rim kao vodeće mjesto u nastanku i razvoju kršćanske umjetnosti. Tekst u knjizi prate brojne ilustracije u čijem izboru dominiraju vrhunska djela europske umjetnosti, među kojima i izabrani primjeri umjetničke produkcije s hrvatskog prostora.

Iznimno je teško pisati pregled specifične likovne produkcije (kao što je rana kršćanska umjetnost) kroz nekoliko stoljeća, na velikom prostoru i u kontekstu. Dino Milinović uspio je ovim djelom rasvijetliti i pojasniti temeljne odrednice nastanka i prvih mijena ranokršćanske umjetnosti, slijedeći suvremene metodološke prakse i propitujući ustaljene obrasce. Upravo su mijene, raznolikost, različite tradicije i suvremene prakse, odnos centara i periferija, izvorišta i utjecaja, obilježile umjetničko djelovanje toga doba, baš kao i vjersko učenje i praksu kako stoji u Pavlovoj poslanici Korinćanima: „Zaklinjem vas, braćo, imenom Gospodina našega Isusa Krista: svi budite iste misli; neka ne bude medu vama razdora, nego budite savršeno istog osjećanja i istog mišljenja. (...) Mislim to što svaki od vas govori: 'Ja sam Pavlov', 'A ja Apolonov', 'A ja Kefin', 'A ja Kristov'. Zar je Krist razdijeljen?’ (1 Kor. 1,10-13). 